\title{
Effect of zinc and lead on the physiological and biochemical properties of aquatic plant Lemna minor: its potential role in phytoremediation
}

\author{
M. A. Jayasri ${ }^{1} \cdot$ K. Suthindhiran ${ }^{1}$
}

Received: 10 June 2014/ Accepted: 28 December 2015/Published online: 21 January 2016

(C) The Author(s) 2016. This article is published with open access at Springerlink.com

\begin{abstract}
Plants have gained importance in situ bioremediation of heavy metals. In the present study, different concentrations of zinc $\left(\mathrm{Zn}^{2+}\right)(0.5,5,10,15,20 \mathrm{mg} / \mathrm{l})$ and lead $\left(\mathrm{Pb}^{2+}\right)(1,2,4,6,8 \mathrm{mg} / \mathrm{l})$ were used to evaluate metal tolerance level of Lemna minor. L.minor were exposed to metals for 4 days and tested for its dry to fresh weight ratio (DW/FW), photosynthetic pigments production and protein content. The oxidative damage was detected by measuring catalase activity. L.minor showed tolerance against $\mathrm{Zn}^{2+}$ and $\mathrm{Pb}^{2+}$ at a concentration of 10 and $4 \mathrm{mg} / \mathrm{l}$, respectively. Among the metals, $\mathrm{Pb}^{2+}$ showed a significant toxicity at $8 \mathrm{mg} / \mathrm{l}$. High concentration $\left(20 \mathrm{mg} / \mathrm{l}\right.$ of $\mathrm{Zn}^{2+}$ and $8 \mathrm{mg} / \mathrm{l}$ of $\mathrm{Pb}^{2+}$ ) of the metals displayed a considerable negative effect on soluble proteins (13 fold decrease with $\mathrm{Zn}^{2+}$ and 4 fold decrease with $\mathrm{Pb}^{2+}$ ) and photosynthetic pigments (twofold decrease with $\mathrm{Zn}^{2+}$ and onefold decrease with $\mathrm{Pb}^{2+}$ ) and lead to a consequent reduction in number of fronds. Further, the catalase was greatly increased (twofold decrease with $\mathrm{Zn}^{2+}$ and sixfold decrease with $\mathrm{Pb}^{2+}$ ) under metal stress. The results indicate that L.minor withstands $\mathrm{Zn}^{2+}$ and $\mathrm{Pb}^{2+}$ toxicity up to the concentration of 10 and $4 \mathrm{mg} / \mathrm{l}$, respectively. Hence, the metal tolerant property of this plant shall be exploited for bioremediation of Zinc and Lead in polluted water. Further, the detailed and wide range of heavy metal toxicity studies should be done to reveal the possible use of this plant on large scale bioremediation purpose.
\end{abstract}

K. Suthindhiran

ksuthindhiran@vit.ac.in; sudhindhira@gmail.com

1 Marine Biotechnology and Bioproducts Lab, Marine Biotechnology and Biomedicine Lab, School of Bio Sciences and Technology, VIT University, Vellore 632 014, Tamil Nadu, India
Keywords Lemna minor - Zinc · Lead · Tolerance · Phytoremediation

\begin{tabular}{ll}
\multicolumn{2}{l}{ Abbreviations } \\
$\mathrm{Zn}^{2+}$ & Zinc \\
$\mathrm{Pb}^{2+}$ & Lead \\
L. minor & Lemna minor \\
CAT & Catalase \\
DW/FW & Dry to fresh weight ratio
\end{tabular}

\section{Introduction}

Urbanization and industrialization had triggered extreme water pollution by draining effluents directly into water bodies without prior treatment. Industries such as smelters, tanneries, metal refineries and mining operations are the major sources of metal release into the environment (Gardea et al. 2004; Srivastava and Thakur 2006). These effluents generally contain metals that can be toxic even in trace amounts and it is very difficult to purify these water bodies due to its large volume. Heavy metal pollution is an important environmental problem in the world because, unlike organic materials, heavy metals cannot be transformed by microorganisms and, therefore, accumulates in water, soil, bottom sediments and living organisms (Miretzky et al. 2004). Most of the heavy metals have been found to be carcinogenic in nature and hence it poses a threat to human health too (Shakibaie et al. 2008; Vinodhini and Narayanan 2009). Metals induce deleterious effect on physiology of aquatic plants by effecting some of the essential phenomenon such as photosynthesis, enzymatic activity, etc. (Teisseire and Vernet 2000; 
Prasad et al. 2001; Vaillant et al. 2005; Kanoun et al. 2009; Zhou et al. 2009) Hence, some eco-friendly and economic methods shall be considered to treat heavy metal polluted water.

Plants have been found to accumulate and concentrate the heavy metals within. Phytotolerance studies are used to determine metal tolerant property of plants and also to determine the detrimental effect of metals on physiological response of plants (Basile et al. 2012; Radić et al. 2010). L.minor, commonly known as Duckweeds are aquatic plants that float on or just beneath the surface of still or slow-moving fresh water bodies and often form dense floating mats in eutrophic ditches and ponds (Driever et al. 2005). It is also used in wastewater treatment to remove mineral and organic contamination and radionuclides (Chaudhary and Sharma 2014; Axtell et al. 2003). The present work deals with the study of the potential of duckweed to grow in different concentrations of metals, viz. Zinc $\left(\mathrm{Zn}^{2+}\right)$ and lead $\left(\mathrm{Pb}^{2+}\right)$ and to assess the tolerance level exhibit by the plant. The metal tolerant efficiency of $L$. minor was evaluated with reference to: (1) dry to fresh weight ratio (DW/FW) (2) changes in soluble protein content; (3) changes in contents of chlorophyll a, chlorophyll b, anthocyanin and carotenoid; (4) changes in enzymatic activity of catalase (CAT) activity.

\section{Materials and methods}

\section{Sample collection}

Duckweed (L.minor) was collected from natural pond water of Vellore Institute of Technology, Vellore.

\section{Plant sample preparation}

Lemna minor fronds were prepared and disinfected in $1 \%$ of sodium hypo chloride solution and $2 \mathrm{~g}$ fronds were then inoculated in synthetic media, i.e., Quarter Coic and Lessaint solution (Khellaf and Zerdaoui 2009) along with various concentrations of lead (1, 2, 4, 6 and $8 \mathrm{mg} / \mathrm{l})$ and zinc $(0.5,5,10,15$, and $20 \mathrm{mg} / \mathrm{l})$ to induce metal stress. Aeration was provided, and fronds were allowed to grow at $25^{\circ} \mathrm{C}$ in an incubator with $16 \mathrm{~h}$ illumination per day provided from fluorescent tubes for 4 days before proceeding with sampling methods. After 4 days of exposure with heavy metals, fronds were collected and stored in the freezer for further analysis like determining biomass, soluble protein, photosynthetic pigments and enzyme assay. A control with untreated fronds was also maintained.

\section{Measurement of dry to fresh weight ratio (DW/FW)}

The number of fronds, fresh weight, and dry weight was calculated as per the ISO/DIS 20079 protocol (2004). Dry to fresh weight ratio (DW/FW) was calculated using the formula dry weight $(\mathrm{g}) /$ fresh weight $(\mathrm{g})$.

\section{Determination of photosynthetic pigments}

The contents of chlorophyll a, chlorophyll b, and carotenoid content of both control and metal treated fronds were determined as described earlier (Lichtenthaler 1987). Briefly, $150 \mathrm{mg}$ of L. minor frond was homogenized with $80 \%$ cold acetone. The homogenate was centrifuged, and the absorbance of the supernatant was measured at 470 , 537, 647, 663 and $730 \mathrm{~nm}$ with a spectrophotometer (Wenhua et al. 2007). Anthocyanin content of both control and metal treated fronds were determined spectrophotometrically as explained by Suzuki (1995).

\section{Catalase assay}

Catalase activity in fronds was measured as described by Wenhua et al. (2007). Approximately 500 grams of $L$. minor fronds treated with lead and zinc of different concentrations were homogenized in $5 \mathrm{ml}$ of cold potassium phosphate buffer, $\mathrm{pH}$ 7.8. The homogenate was centrifuged at $9000 \mathrm{rpm}$ for $15 \mathrm{~min}$ with a temperature of $4{ }^{\circ} \mathrm{C}$ and supernatant were stored at $4{ }^{\circ} \mathrm{C}$ for analysis. The reaction mixture $(1 \mathrm{ml})$ containing potassium phosphate buffer $(50 \mathrm{mM}, \mathrm{pH} 7.5,750 \mu \mathrm{l}), \mathrm{H}_{2} \mathrm{O}_{2}(200 \mathrm{mM}, 100 \mu \mathrm{l})$ and enzyme extract $(150 \mu \mathrm{l})$ was evaluated for catalase activity by measuring the consumption of $\mathrm{H}_{2} \mathrm{O}_{2}$ spectrophotometrically at $240 \mathrm{~nm}$ (Wenhua et al. 2007).

\section{Protein estimation}

Approximately 500 grams of $L$. minor fronds were crushed in pestle and mortar with $5 \mathrm{ml}$ of potassium phosphate buffer, collected into $15 \mathrm{ml}$ centrifuge tube and centrifuged at 12,000 rpm for $20 \mathrm{~min}$. The clear supernatant was taken and used for estimation of protein by Lowry's Method (Lowry et al. 1951).

\section{Results and discussion}

\section{Effect on dry to fresh weight ratio (DW/FW)}

After 4 days of exposure to zinc and lead the physiological and morphological conditions were analyzed. The frond samples with green color and with no signs of necrosis 
were taken for further analysis. Dry to fresh weight ratio (DW/FW) was measured after 4 days. Comparatively, the biomass yield in fronds treated with a lower concentration $(0.5 \mathrm{mg} / \mathrm{l})$ of $\mathrm{Zn}^{2+}$ was higher $(30 \%)$ than the control. $10 \mathrm{mg} / \mathrm{l}$ had little effect on growth while $20 \mathrm{mg} / \mathrm{l}$ retarded the growth after 4 days. The zinc at lower concentration promotes the growth of duckweeds, but it becomes toxic to the duckweed at higher concentration. Similarly, the lead induced stress also had a negative impact on the growth of L. minor. At $6 \mathrm{mg} / \mathrm{l}$ concentration, the biomass was drastically reduced by $80 \%$. Both the metals at higher concentration are known to interfere with the photosystem alteration and resultantly induce the chlorosis.

It has been found that duckweed shows wide range of tolerance against several factors that generally leads to necrosis and hence causes death in many plants. These macrophytes can tolerate a wide $\mathrm{pH}$ range but survive best between $\mathrm{pH}$ of $4.5-8.3$. It is also used in wastewater treatment to remove mineral and organic chemicals and radionuclides (Susarla et al. 2002). Results obtained in the present study shows the tolerance of $L$. minor to the highest concentration of metals to which it was exposed; i.e.; 10 and $4 \mathrm{mg} / \mathrm{l}$ of the concentration of $\mathrm{Zn}^{2+}$ and $\mathrm{Pb}^{2+}$, respectively. It has already been shown in some studies that the metals like $\mathrm{Pb}$ and $\mathrm{Zn}$ were tolerated by L. minor at 0.4 , $0.4,3$ and $15 \mathrm{mg} / \mathrm{l}$, respectively (Khellaf and Zerdaoui 2009; Sasmaz et al. 2015). In our observations, it is evident that the duckweeds tolerate the zinc up to $10 \mathrm{mg} / \mathrm{l}$.

\section{Effect of Zinc and $\mathrm{Pb}$ on soluble protein in Lemna minor}

Variations in soluble protein content can be considered as a sign of some physiological changes in plant metabolism (Singh and Tewari 2003). Changes in the soluble protein content of L. minor, when treated with different concentrations of $\mathrm{Zn}^{2+}$ and $\mathrm{Pb}^{2+}$, were shown (Figs. 1,2). The soluble protein content in $L$. minor decreased by an increase in the concentration of $\mathrm{Zn}^{2+}$. Exposure to $0.5 \mathrm{mg} / \mathrm{l}$ of $\mathrm{Zn}^{2+}$ showed only a slight decrease in soluble protein when compared to the control content after 4 days of treatment. However, exposure to $10 \mathrm{mg} / \mathrm{l}$ of $\mathrm{Zn}^{2+}$ showed a $75 \%$ protein content reduction in L. minor. Beyond $10 \mathrm{mg} / 1$ of $\mathrm{Zn}^{2+}$ indicated more than $90 \%$ decrease in protein content (Fig. 1). The soluble protein content of $L$. minor fronds exposed to different concentrations of lead was also found to decrease on the consequent increase in the concentration of lead. From 0 to $4 \mathrm{mg} / \mathrm{l}$ concentration, there was a gradual reduction in the protein content. At a concentration of $8 \mathrm{mg} / \mathrm{l}$, the plant showed almost same level of protein content as compared to the frond exposed to $6 \mathrm{mg} / \mathrm{l}$ (Fig. 2).

Decrease in total soluble protein content after exposure to metals could be due to changes in metabolism caused

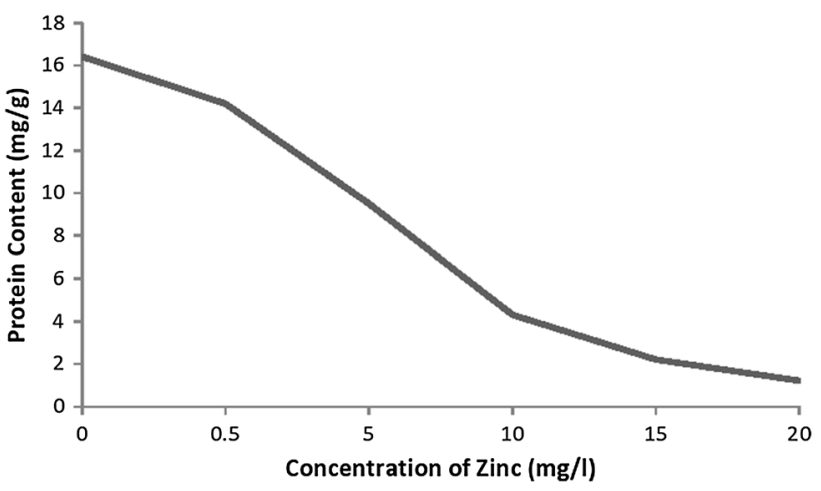

Fig. 1 Effect of various concentrations of Zinc on the soluble protein of Lemna minor

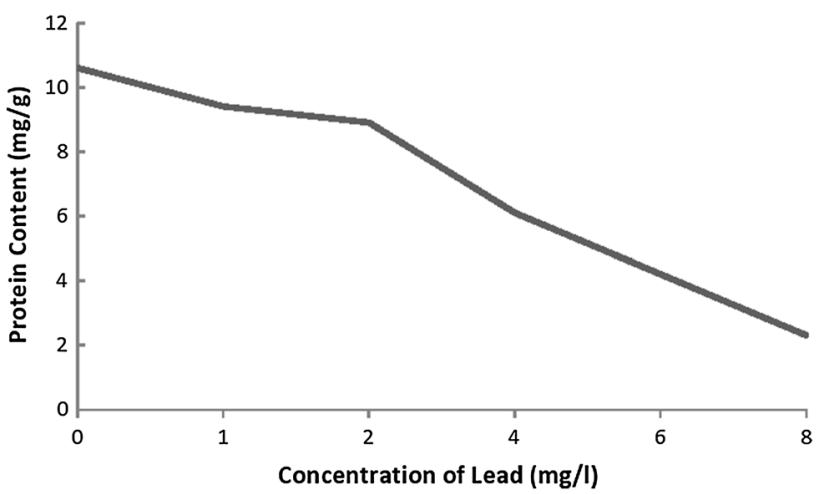

Fig. 2 Effect of various concentrations of Lead on the soluble protein of. Lemna minor

due to metal stress. Exposure of plants with heavy metals could also induce synthesis of some proteins related to stress to overcome the effects of heavy metal stress which show an increase in protein content (Doganlar et al. 2012). The above results clearly indicate that zinc and lead considerably affect the physiology of plant $L$. minor. Zinc and lead have a significant toxic effect on soluble proteins present in $L$. minor, and hence, leads to a consequent decrease in soluble protein with an increase in the concentration of metal and stress. Heavy metals had been found to have a strong inhibition effects on soluble protein and photosynthetic pigments of $L$. minor (Wenhua et al. 2007). Proteins represent the reversible and irreversible changes in the physiological state of the biological system and hence from above results we may infer that metal stress highly disturbs the homeostasis and normal metabolism in the plant L. minor (Singh and Tewari 2003).

\section{Effect on photosynthetic pigments}

Different trends were observed for different pigments in the heavy metal exposed L.minor fronds. The pigment contents in L.minor fronds treated with different 
Table 1 Effect of various concentrations of zinc on photosynthetic pigment of Lemna minor

\begin{tabular}{|c|c|c|c|c|c|c|}
\hline \multirow[t]{2}{*}{ Pigments } & \multicolumn{6}{|c|}{ Concentrations $\left(\mathrm{mgl}^{-1}\right)$} \\
\hline & $\mathrm{C}$ & 0.5 & 5 & 10 & 15 & 20 \\
\hline Chlorophyll a & 0.19 & 0.23 & 1.82 & 1.29 & 0.77 & 0.66 \\
\hline Chlorophyll b & 0.60 & 0.74 & 0.94 & 0.20 & 0.10 & 0.11 \\
\hline Total chlorophyll & 0.79 & 0.68 & 0.89 & 0.56 & 0.32 & 0.30 \\
\hline Anthocyanin & 0.0078 & 0.0097 & 0.069 & 0.035 & 0.021 & 0.013 \\
\hline Carotenoid & 0.10 & 0.66 & 0.75 & 0.43 & 0.38 & 0.21 \\
\hline
\end{tabular}

Table 2 Effect of various concentrations of lead on photosynthetic pigments of Lemna minor

\begin{tabular}{lllllll}
\hline Pigments & \multicolumn{2}{l}{ Concentrations $\left(\mathrm{mgl}^{-1}\right)$} & & \\
\cline { 2 - 6 } & $\mathrm{C}$ & 1 & 2 & 1.65 & 6 \\
\hline Chlorophyll a & 1.75 & 1.97 & 0.61 & 1.24 & 0.99 \\
Chlorophyll b & 0.71 & 3.46 & 3.27 & 0.45 & 0.33 & 0.31 \\
Total chlorophyll & 3.17 & 0.051 & 0.036 & 0.026 & 3.01 & 0.020 \\
Anthocyanin & 0.024 & 0.50 & 0.39 & 0.38 & 0.33 \\
Carotenoid & 0.79 & & & 0.012 \\
\hline
\end{tabular}

concentrations of $\mathrm{Zn}^{2+}$ and $\mathrm{Pb}^{2+}$ are shown in Table 1 and 2. The $\mathrm{Zn}^{2+}$ concentrations used were $0.5,5,10,15$ and $20 \mathrm{mg} / \mathrm{l}$. The amount of Chlorophyll a was found highest $5 \mathrm{mg} / \mathrm{l}$ of $\mathrm{Zn}^{2+}$ (1.82) whereas in control, it was found to be 0.19 . A gradual decrease in chlorophyll a was seen when $\mathrm{Zn}^{2+}$ concentration was further increased. In the case of chlorophyll b $5 \mathrm{mg} / \mathrm{l}$ concentration of $\mathrm{Zn}^{2+}$ yielded highest (0.94) as compared to that of control (0.60). The chlorophyll $b$ was gradually decreased with as increasing concentration of $\mathrm{Zn}^{2+}$. A similar pattern was obtained in total chlorophyll, higher (0.89) at $5 \mathrm{mg} / \mathrm{l}$ concentration of $\mathrm{Zn}^{2+}$ and decreased as the concentration was elevated. Anthocyanin was found to be in its maximum (0.0097) at a concentration of $0.5 \mathrm{mg} / \mathrm{l}$ while control showed 0.0078 and a steady decrease was seen when the concentration was increased. Carotenoid showed maximum $(0.75)$ at $5 \mathrm{mg} / \mathrm{l}$ of $\mathrm{Zn}^{2+}$ concentration, and it was decreased beyond that concentration.

The effect of $\mathrm{Pb}^{2+}$ on photosynthetic pigments of $L$. minor showed a variance in the pigment production with increased concentration of $\mathrm{Pb}^{2+}$. All pigments such as chlorophyll a, chlorophyll b, total chlorophyll and anthocyanin exhibited initial increase from the control and gradual decrease as the concentration of the $\mathrm{Pb}^{2+}$ was increased. Chlorophyll a had highest (1.97) at a concentration of $1 \mathrm{mg} / \mathrm{l}$. Higher amount was observed with $1 \mathrm{mg} / \mathrm{l}$ concentration for Chlorophyll $\mathrm{b}$ (0.87), total chlorophyll (3.46) and anthocyanin (0.051) as well. Whereas carotenoid showed a gradual decrease from the control (0.79) when varying the concentration of $\mathrm{Pb}^{2+}$ was administered.
Further, the results obtained also indicate that metal stress, on an average, decreases the expression of photosynthetic pigments. From Tables 1 and 2, it could be inferred that the rate of degradation of Chlorophyll $b$ under heavy metal stress of zinc and lead was slower than that of Chlorophyll a and carotenoid, respectively. Hence, the effect of heavy metals on Chlorophyll a is greater than that of Chlorophyll b. As it is evident that Chlorophyll a is one of the most important center pigments in photosynthesis, therefore, reduced amount of Chlorophyll a can inhibit the photosynthesis greatly. Carotenoid, which usually plays an important role in protecting chlorophyll, also serves as an antioxidant to quench or scavenge the free radicals and prevents the damage of cell, cell membrane, and its main genetic composition (Han 1999). In the present study where the concentration of carotenoid is found to decrease on its exposure to Zinc and Lead, therefore, the susceptibility of plant tissue of $L$. minor towards damage also increases significantly. The mechanism of effect of heavy metals on plant level of photosynthetic pigments may be owed to three reasons. First, heavy metals enter frond chloroplast (Sandalio et al. 2001) and may get over-accumulated locally causing oxidative stress that will cause damages like peroxidation of chloroplast membranes (Puertas et al. 2004). They can also directly destroy the structure and function of chloroplast by binding with - $\mathrm{SH}$ group of the enzyme and may also inhibit the overall chlorophyll biosynthesis by targeting $\mathrm{Mg}^{2+}$ and $\mathrm{Fe}^{2+}$. Second, heavy metal ions inhibit uptake and transportation of other metal elements such as Manganese and Iron by 
antagonistic effects and therefore, the fronds lose their capacity to synthesize pigments (Das et al. 1997). Third, Heavy metals may activate pigment enzyme and accelerate the decomposition of pigment (Wenhua et al. 2007). On comparing the results of the responses produced by $L$. minor under the metal stress of $\mathrm{Pb}^{2+}$ and $\mathrm{Zn}^{2+}$, this can be clearly observed that $\mathrm{Pb}^{2+}$ induces more uniform and significant alteration in the physiological processes of $L$. minor as compared to $\mathrm{Zn}^{2+}$. As it is known, that $\mathrm{Zn}$ application increases plant chlorophyll and protein contents; thereby plant can utilize and tolerate higher levels of Zinc concentration (Samreen et al. 2013; Lin and Wu 1994). Hence, $\mathrm{Pb}^{2+}$ is more potent and toxic towards $L$. minor than $\mathrm{Zn}^{2+}$.

\section{Effect of $\mathrm{Zn}$ and $\mathrm{Pb}$ on CAT activity of L.minor}

Increased production of reactive oxygen species occurs in plants under environmental stresses, such as heavy metals, salt stress, ultraviolet radiation, air pollution such as ozone and $\mathrm{SO}_{2}$ (Mittler et al. 2002). Under these stress conditions antioxidant enzymes like CAT, SOD will be activated by plants as a mode of detoxification to scavenge excess reactive oxygen species. This study shows a significant increase in the CAT activity in the presence of $\mathrm{Pb}^{2+}$ and $\mathrm{Zn}^{2+}$ (Figs. 3,4). The increased activity of CAT in the presence of $\mathrm{Pb}^{2+}$ and $\mathrm{Zn}^{2+}$ indicates the increased amounts of hydrogen peroxide and additionally effective scavenging of $\mathrm{H}_{2} \mathrm{O}_{2}$. The maximum value for CAT activity under zinc stress was observed at the concentration of $5 \mathrm{mg} / \mathrm{l}(8.2 \mathrm{U} \mathrm{mg} /$ protein/ min). However, the activity was found to be gradually decreased upon increased concentration. At the concentration of $20 \mathrm{mg} / \mathrm{l}$, the activity was found to be $4.9 \mathrm{U} \mathrm{mg} / \mathrm{pro}-$ tein/min. In the L. minor fronds under $\mathrm{Pb}^{2+}$ stress, an exponential increase in CAT activity was observed. Figure 4 shows the dose dependent CAT activity observed in L. minor fronds. Maximum activity $(28.0 \mathrm{U} \mathrm{mg} /$ protein $/ \mathrm{min})$ was found at the concentration of $8 \mathrm{mg} / \mathrm{l}$ of lead. A continuous increase in the CAT activity was observed with increasing concentration of $\mathrm{Pb}^{2+}$. At a concentration of $1 \mathrm{mg} / \mathrm{l} \mathrm{of} \mathrm{Pb}^{2+}$, the catalase activity was seen to be less ( $5 \mathrm{U} \mathrm{mg} /$ protein/min) while it increased at higher concentrations of $\mathrm{Pb}^{2+}$. The results show similar findings with earlier reports showing the effects of Mn and Ni on CAT activity in this plant (Fridovich 1978). When Lemna was faced with low-level metal stress, fronds could activate CAT activities, which led to a strengthening of fronds, to scavenge ROIs responsible for lipid peroxidation (Fridovich 1978). While the activities decreased distinctly under too acute stress that overloaded cellular defense system of fronds (Guecheva et al. 2003; Lichtenthaler 1996). Reduction in the activities of CAT might be due to the formation of a protein complex with metals that resulted in the structural integrity of proteins

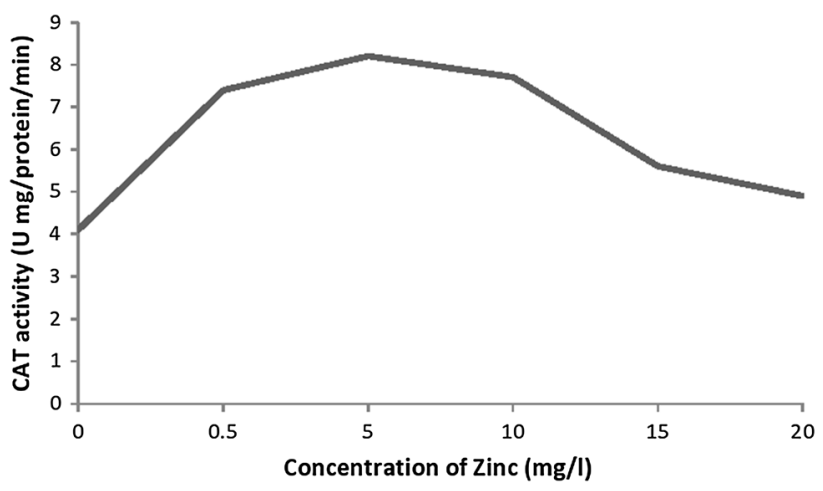

Fig. 3 Effect of various concentrations of Zinc on CAT activity of Lemna minor

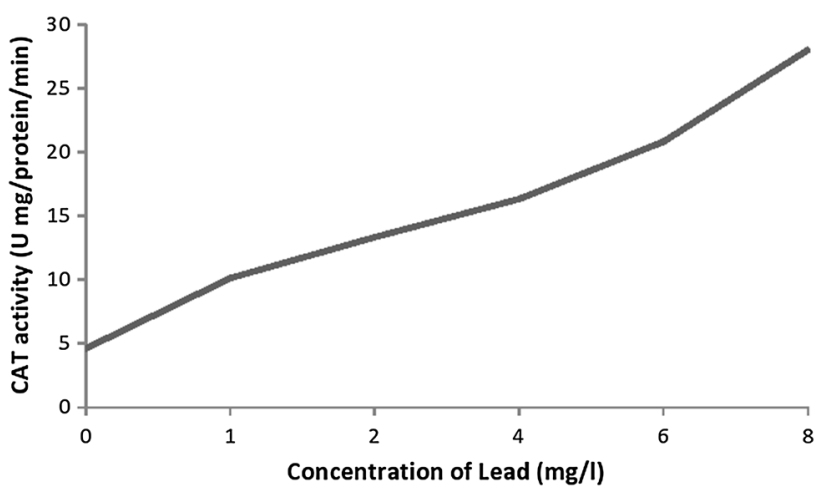

Fig. 4 Effect of various concentrations of Lead on CAT activity of Lemna minor

(Florence 1986; Mohan et al. 1997). The results suggest that $\mathrm{Pb}^{2+}$ was more toxic to L. minor than $\mathrm{Zn}^{2+}$ for the reason that at relatively lower concentrations, antioxidant system appeared to be in disorder.

The present study indicates that under metal stress the CAT activity was increased in an exponential order, in the case of lead and showed a biphasic response in case of Zinc. CAT participates in the main defense system against accumulation and toxicity of hydrogen peroxide and can play the role in controlling $\mathrm{H}_{2} \mathrm{O}_{2}$ level in cells. It acts on $\mathrm{H}_{2} \mathrm{O}_{2}$ and converts it to water and oxygen (Mstte's 2000). The present study shows that enzymatic activity of $L$. minor increases with increase in metal concentration.

\section{Conclusion}

L. minor shows tolerance against the high metal concentration of 10 and $4 \mathrm{mg} / \mathrm{l}$ of $\mathrm{Zn}^{2+}$ and $\mathrm{Pb}^{2+}$, respectively. Among these, $\mathrm{Pb}^{2+}$ was found to be more toxic and potent against $L$. minor. Hence, $L$. minor can be used for the bioremediation of low-level polluted water body by Zinc and Lead. However, large scale studies should be done on 
the tolerance level against a wide range of heavy metals and also on other biochemical and physiological factors. This will imply the $L$. minor for recommended usage on a large scale for treating polluted water resources by cheap and eco-friendly approach. The present work will provide a greater insight to the study of L. minor species and its relevance to be used for in situ bioremediation on a large scale that puts forward a cheap and convenient method for treating polluted water.

Acknowledgments This study is supported by the institutional grant, and the authors wish to thank the management of VIT University for providing necessary facilities.

Author's contributions MAJ and KS have designed the study and performed the statistical analysis. MAJ performed the experiments, collected the data and analyzed. KS drafted the manuscript, analyzed the data critically and validated. Both the authors approve the manuscript.

Conflict of interest The authors declare that they have no conflict of interest.

Open Access This article is distributed under the terms of the Creative Commons Attribution 4.0 International License (http:// creativecommons.org/licenses/by/4.0/), which permits unrestricted use, distribution, and reproduction in any medium, provided you give appropriate credit to the original author(s) and the source, provide a link to the Creative Commons license, and indicate if changes were made.

\section{References}

Axtell NR, Sternberg SP, Claussen K (2003) Lead and nickel removal using Microspora and Lemna minor. Bioresour Technol 89:41-48

Basile A, Sorbo S, Conte B, Cobianchi RC, Trinchella F, Capasso C, Carginale V (2012) Toxicity, accumulation, and removal of heavy metals by three aquatic macrophytes. Int $\mathrm{J}$ Phytorem 14:374-387

Chaudhary E, Sharma P (2014) Duckweed Plant: a Better future option for phytoremediation. IJESE 2:2319-6378

Das P, Samantaray S, Rout GR (1997) Studies on cadmium toxicity in plants: a review. Environ Pollut 98:29-36

Doganlar ZB, Seher C, Telat Y (2012) Metal uptake and physiological changes in Lemna gibba exposed to manganese and nickel. Int J Biol. doi:10.5539/ijb.v4n3p148

Driever SM, Egbert HVN, Rudi MMR (2005) Growth limitation of Lemna minor due to high plant density. Aquat Bot 81:245-251

Florence TM, Staube JL (1986) Toxicity of copper complexes to the marine diatom Nitzschia closterium. Aquat Toxic 8:11-26

Fridovich I (1978) The biology of oxygen radicals. Science 201:875-880. doi:10.1126/science.210504

Gardea TJL, de la Rosa G, Peralta VJR (2004) Use of phytofiltration technologies in the removal of heavy metals: a review. Pure Appl Chem 76:801-813

Guecheva TN, Erdtmann B, Benfato MS (2003) Stress protein response and catalase activity in freshwater planarian Dugesia (Girardia) schubarti exposed to copper. Ecotoxicol Environ Saf 56:351-357

Han YS (1999) Advances of the function of Beta-carotene and carotenoid. J China Agric Univ 4:5-9
ISO/DIS 20079 (2004) Water quality-determination of the toxic effect of water constituents and waste water to duckweed (Lemna minor)—duckweed growth inhibition test. ISO TC 147/SC 5/WG 5

Kanoun BM, Vicente Joaquim AF, Nabais Cristina, Prasad MNV, Freitas Helena (2009) Ecophysiological tolerance of duckweeds exposed to copper. Aquat Toxicol 91:1-9

Khellaf N, Zerdaoui M (2009) Growth responses of the duckweed Lemna minor to heavy metal pollution. Iran J Environ Health Sci Eng 6:161-166

Lichtenthaler HK (1987) Chlorophylls and carotenoids: pigments of photosynthetic membranes. Method Enzymol 148:350-382

Lichtenthaler HK (1996) Vegetation stress: an introduction to the stress concept in plants. J Plant Physiol 148:4-14

Lin S, Wu L (1994) Effects of copper concentration on mineral nutrient uptake and copper accumulation in protein of copper tolerant and non-tolerant Lotus purshianus. Ecotox Environ Safe 29:214-228

Lowry HO, Rosebrough NJ, Farr LA, Randall JR (1951) Protein measurement with the folin phenol reagent. J Biol Chem 193:265-275

Miretzky P, Andrea S, Alicia FC (2004) Aquatic macrophytes potential for the simultaneous removal of heavy metals (Buenos Aires, Argentina). Chemosphere 57:997-1005

Mittler R (2002) Oxidative stress, antioxidants and stress tolerance. Trends Plant Sci 17:405-410

Mohan BS, Hosetti BB (1997) Potential phytotoxicity of lead and cadmium to Lemna minor grown in sewage stabilization ponds. Environ Pollut 98:233-238

Msttés JM (2000) Effects of antioxidant enzymes in the molecular control of reactive oxygen species toxicology. Toxicology 153:83-104

Prasad MNV, Malec P, Waloszek A, Bojko M, Strzalka K (2001) Physiological responses of Lemna trisulca L. (duckweed) to cadmium and copper bioaccumulation. Plant Sci 161:881-889

Puertas RMC, Rodriguez SM, Corpas FJ (2004) Cadmium-induced subcellular accumulation of oxygen and hydrogen peroxide in pea leaves. Plant Cell Environ 27:1122-1134

Radić S, Babić M, Škobić D, Roje V, Pevalek-Kozlina B (2010) Ecotoxicological effects of aluminum and zinc on growth and antioxidants in Lemna minor L. Ecotoxicol Environ Saf 73:336-342

Samreen T, Shah HU, Ullah S, Javid M (2013). Zinc effect on growth rate, chlorophyll, protein and mineral contents of hydroponically grown mungbeans plant (Vigna radiata). Arab J Chem

Sandalio LM, Dalurzo HC, Gomez M (2001) Cadmium-induced changes in the growth and oxidative metabolism of pea plants. J Exp Bot 52:2115-2126

Sasmaz M, Topal EIA, Obek E, Sasmaz A (2015) The potential of Lemna gibba $\mathrm{L}$. and Lemna minor $\mathrm{L}$. to remove $\mathrm{Cu}, \mathrm{Pb}, \mathrm{Zn}$, and As in gallery water in a mining area in Keban, Turkey. J Environ Manag 163:246-253

Shakibaie MR, Khosravan A, Farmhand A, Zare S (2008) Application of metal resistant bacteria by mutational enhancement technique for bioremediation of copper and zinc from industrial wastes. Iran J Environ Health Sci Eng 5:251-256

Singh PK, Tewari RK (2003) Cadmium toxicity induced changes in plant water relations and oxidative metabolism of Brassica juncea L. Plants. J Environ Biol 24:107-112

Srivastava S, Thakur IS (2006) Isolation and process parameter optimization of Aspergillus sp. for removal of chromium from tannery effluent. Bioresource Technol 97:1167-1173

Susarla S, Medina VF, McCutcheon SC (2002) Phytoremediation: an ecological solution to organic chemical contamination. Ecol Eng 18:647-658 
Suzuki M (1995) Enhancement of anthocyanin accumulation by high osmotic stress and low $\mathrm{pH}$ in grape cells (Vitis hybrids). J Plant Physiol 147:152-155

Teisseire H, Vernet G (2000) Copper-induced changes in antioxidant enzymes in fronds of duckweed (Lemna minor). Plant Sci 153:65-72

Vaillant N, Monnet F, Hitmi A, Sallanon H, Coudret A (2005) Comparative study of responses in four Datura species to a zinc stress. Chemosphere 59:1005-1013

Vinodhini R, Narayan M (2009) The impact of toxic heavy metals on the hematological parameters in common carp (Cyprinus carpio L.). Iran J Environ Health Sci Eng 6:23-28
Wenhua H, Xiao C, Guanling S, Qunhui W, Chein CC (2007) Effects of copper and cadmium on heavy metal polluted waterbody restoration by duckweed (Lemna minor). Plant Physiol Biochem 45:62-69

Zhou N, Zheng B, He Y (2009) Short time domain wall dynamics in the random field using model with a driving field. Phys Rev B. doi:10.1103/PhysRevB.80.134425 